\title{
UNITED NA
}

UNITED NATIONS PUBLICATIONS covers questions dealing with many subjects in the African region. For a detailed picture of the UN publishing programme send for our catalogues, free of charge:

- Standing Order Service Guide

- UN Official Records

- UN Publications in Print 1983/1984

- Microfiche Price List

- Introductory Catalogue

\section{YEARBOOK OF THE UNITED NATIONS, Volume 34}

The Yearbook is the principal reference work. of the United Nations, offering a comprehensive, one-volume account of the Organization's wide-ranging work during 1980, providing what the Secretary-General calls "a record of the efforts made by the Organization over the course of one year to edge closer to the great ideals of the Charter."

E.83.1.1

$\$ 72.00$

\section{WORLD ECONOMIC SURVEY 1983 \\ CURRENT TRENDS AND POLICIES IN THE WORLD ECONOMY}

Provides an appraisal of current trends in the world economy, their effects on development and the requirements for international co-operation.

E.83.11.C.1

\section{TRANSNATIONAL CORPORATIONS IN WORLD DEVELOPMENT:}

\section{THIRD SURVEY}

Contains an overview of TNC in World Development, Foreign Investment: changing patterns in the market economies, policies with respect to TNC, recent trends in Contractual Arrangements, TNC in selected sectors, TNC and Trade and Technology transfer.

E.83.11.A.14

$\$ 38.00$

\section{EXPLOITATION OF CHILD LABOUR}

Final Report submitted by Abdelwahub Bouhdiba, Special Rapporteur of the Sub-Commission on Prevention of Discrimination and Protection of Minorities.

E.82.XIV.2

INTERNATIONAL MIGRATION, POLICIES AND PROGRAMMES: A WORLD SURVEY

Population Studies No. 80

E.82.XIII.4 


\section{The Journal of African History}

Editors

MICHAEL BRETT

School of Oriental and African Studies, University of London

CHRISTOPHER FYFE

Centre of African Studies, University of Edinburgh

J. FORBES MUNRO

Department of Economic History, University of Edinburgh

ANDREW ROBERTS

School of Oriental and African Studies, University of London

The Journal of African History publishes articles and reviews ranging widely over the African past from the Late Stone Age to the present. Since its establishment in 1960, it has aimed to reflect all the major interests of historians of Africa, and has included contributions from specialists in a variety of disciplines, including archaeology, botany and comparative philology. Recent issues have devoted increasing space to economic history and to the colonial period. The journal seeks to present the results of new research in the broader context of historical change whether on a regional or continental scale. Contributions are welcomed in English or French. The

contents include research articles, review articles and book reviews.

\section{Volume 24, Number 2, June 1983}

This is a Special issue on the history of the family in Africa. It contains articles selected by two guest editors, Dr. Shula Marks and Dr. Richard Rathbone.

The articles are selected from papers originally presented to a conference held at the School of Oriental and African Studies under the joint auspices of the School and the British Social Science Research Council, in September 1981. The conference grew out of the editors' concern that the history of the family, which had become so lively and important an area of study in Europe and

America since the $1960 \mathrm{~s}$, was being almost totally neglected in Africa.

The editors hope to stimulate research on a range of questions which could be fruitfully explored in the African context, and which could possibly feed into

the wider historiography on the family in Britain, America and Europe.

If you would like further information on the Special/ssue please contact Aileen Askwith, Journals Publicity Controller, at the address below.

Volume 24: March, June, August and November 1983

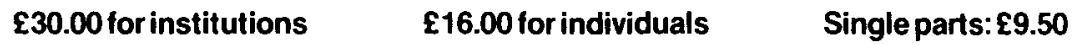

Airmail £13.25 extra per volume (1983)

CAMBRIDGE UNIVERSITY PRESS

The Edinburgh Building, Shaftesbury Road, Cambridge CB2 2RU, England

(ii) 


\section{AFRICAN QUOTATIONS}

Wanted: Contemporary and historical epigrams, bon mots, and other quotes on Africa south of the Sahara. The Oxford book of quotations has only five entries on Africa and none by Africans. Please send us your favorite quotes by Africans or about Africa. Pithiness preferred. We seek not traditional proverbs but insightful quotes from speeches, articles, and books. Your contributions will be acknowledged in the forthcoming publication.

Munger Africana Library Pasadena, California 91125, U.S.A.

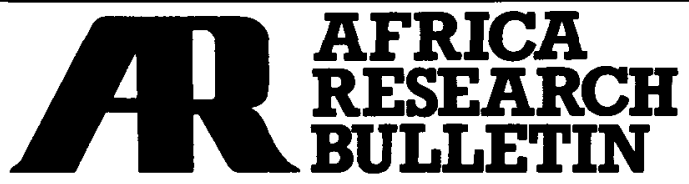

Since 1964, the invaluable aid to the study of contemporary Africa.

Every month, the Africa Research Bulletin gathers significant fact and comment from over 100 local sources including press and radio, complementing these with information from government gazettes, international agencies and the European and American press. Information is selected impartially and all sources are acknowledged. Each issue is comprehensively indexed and subscribers also receive a cumulative annual index. Cross-references guide readers to previous issues of the Bulletin. The end result is both a concise summary and continuing record, covering the entire Continent.

The Bulletin is published monthly in two Series: a) Political, Social and Cultural Series b) Economic, Financial and Technical Series

All previous annual sets available.

Subscription rates and specimen copies from:

AFRICA RESEARCH LTD, IA SUMMERLAND ST, EXETER EXI 2AF, DEVON, ENGLAND. TEL EXETER (0392) 215655 


\section{New Perspectives and Conceptions of International Law}

\section{An Afro-European Dialogue}

\section{Edited by Konrad Ginther and Wolfgang Benedek}

Institute of International Law and International Relations, University of Graz, Austria

With contributions from Ethiopia, Kenia, Nigeria, Swasiland, Zaire, Zambia, Zimbabwe, Austria, and the Federal Republic of Germany

The quest for new perspectives and conceptions of international law discussed in this book is a response to the transition in international relations from a Euro-centric, status quo-oriented state system to a geocentric, development-oriented one.

The contributions, focusing on New International Economic Order, Human Rights, and National Liberation in Southern Africa, are based on a workshop, which was jointly organized by African and European international law teachers at the University of Zimbabwe in 1982. On this occasion, new perspectives and conceptions of international law were elaborated in a new co-operative approach and on the basis mainly of African material on international law which has largely been neglected until now.

This publication is the product of what can be understood as a new mode of growth of international law as an academic discipline, through which the relevance of international law to the most urgent problems of our time ought to be enhanced.

1983. IX, 261 pages. ISBN 3-211-81780-8

Soft cover DM 49,-, approx. US $\$ 19.00$, approx. £ 13.00

\section{Springer-Verlag Wien New York}

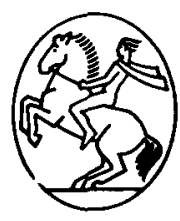




\section{THE JOURNAL OF MODERN AFRICAN STUDIES}

The Fournal offers a quarterly survey of politics, economics, and related topics in contemporary Africa.

The main emphasis is upon the peoples and policies, the problems and progress of this dynamic and disparate continent; upon the many societies that are evolving rather than the essential characteristics of the old; upon the present, not on the more distant past. The best current work is sought from specialists in different academic disciplines, whose contributions can illuminate and crossfertilise one another.

The Fournal seeks to promote a deeper understanding of what is happening in Africa today. It is intended for both the political scientist and the practical politician, the administrator and the advocate, the economist and the educator, the banker and the business man, the diplomat and the technocrat, the civil servant and the nationalist leader. All have something to contribute to these pages and, it is hoped, much to learn from them.

Editorial policy avoids commitment to any political viewpoint or ideology, whether imperialism, pan-Africanism, capitalism, socialism, or nationalism. Such concepts, however, have relevance to the modern African situation, and merit serious discussion, often from several different points of view, in order that controversial issues may be fairly examined.

\section{(C) Cambridge University Press 1983}

Contributors of accepted articles will be asked to assign their copyright, on certain conditions, to Cambridge University Press, to help protect their material, particularly in the U.S.A.

\section{Copying}

This journal is registered with the Copyright Clearance Center, 2 I Congress St., Salem, Mass. or970. Organisations in the U.S.A. who are also registered with C.C.C. may therefore copy material (beyond the limits permitted by sections 107 and 108 of U.S. copyright law) subject to payment to C.C.C. of the per copy fee of $\$ 05.00$. Code 0022-278x/83/2828-000I \$05.00. This consent does not extend to multiple copying for promotional or commercial purposes.

ISI Tear Service, 350 I Market Street, Philadelphia, Pennsylvania I9 104, U.S.A., is authorised to supply single copies of separate articles for private use only.

For all other use, permission should be sought from the Cambridge or New York offices of the Cambridge University Press. 


\section{CAMBRIDGE UNIVERSITY PRESS}

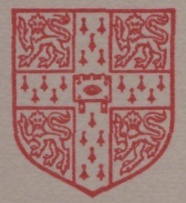

The Pitt Building, Trumpington Street, Cambridge CB2 1RP

32 East 57 th Street, New York, N.Y. 10022

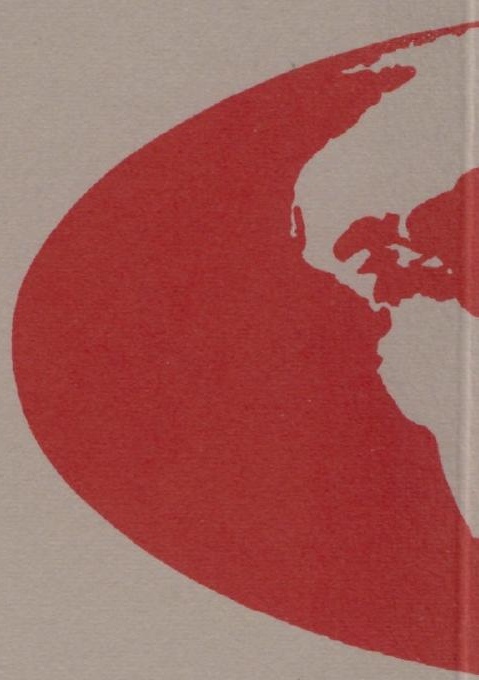

(C) Cambridge University Press 1983 